Prof. Aleksandar S. Mojašević, LL.D.,"

Associate Professor,

Faculty of Law, University in Niš
ПРЕГЛЕДНИ НАУЧНИ РАД

doi:10.5937/zrpfn0-23189

UDK: $34: 159.9$

$330: 159.9$

Рад примљен: 16.09.2019.

Рад прихваћен: 18.10.2019.

\title{
BEHAVIORAL LAW AND ECONOMICS: MULTIDISCIPLINARITY IN ACTION ${ }^{* *}$
}

\begin{abstract}
This paper presents the theoretical foundations of Behavioral Law and Economics (BLE), as well as the practical implications of some key findings of this discipline. The author examines the roots of this discipline, its development, the most important representatives and opponents, and, most importantly, the boundaries of this discipline in relation to the neoclassical Law and Economics (L\&E), on the one hand, and Behavioral Economics, on the other hand. Since BLE "borrows" certain findings from psychology (especially from social psychology), it raises the issue of interconnection between these two disciplines, which will be analyzed en passant. The central questions that need to be addressed are whether BLE is a special and sufficiently developed scientific discipline, or is it only a theoretical upgrade over its base (the neoclassical L\&E), and what are the practical achievements and significance of its key findings in the field of dispute resolution policy?
\end{abstract}

Keywords: Behavioral Law and Economics, Economic Analysis of Law, Behavioral Economics, theoretical foundations, practical findings.

\footnotetext{
*mojasevic@prafak.ni.ac.rs

${ }^{* *}$ This article is the result of research within the project "Protection of Human and Minority Rights in the European Legal Area", funded by the Ministry of Education and Science of the Republic of Serbia (reference number 179046).

${ }^{* *}$ The paper was presented under the same title at the International Scientific Conference "Law and Multidisciplinarity", held at the Faculty of Law, University in Niš, Serbia, 12th-13th April 2019.
} 


\section{Introduction}

The traditional neoclassical Economic Analysis of Law (EAL), or Law and Economics (L\&E), is already well established and developed scientific discipline. Yet, perhaps the greatest challenge to this discipline is the development of behavioral science ${ }^{1}$ which, through numerous empirical studies, calls into question the classical tenets of economic analysis and EAL.

This article explores the relationship between these disciplines. In the first part of the paper, the author presents the definition and the subject matter of EAL, as well as the subject matter of Behavioral Economics (BE) and Behavioral Law and Economics (BLE). In presenting the subject matter and the key concepts of these disciplines (EAL, BE and BLE), the author seeks to answer the key question: will behavioral findings undermine the EAL foundations, or do they only represent an upgrade of already developed economic models, enriching their content? Related to this is the question of whether BLE will have an independent scientific development path.

\section{Definition and subject matter of Economic Analysis of Law}

Economic Analysis of Law (EAL) may be defined as "the application of economic theory and econometric methods to examine the formation, structure, processes and impact of law and legal institutions" (Rowley, 1989: 125). The subject matter of study in EAL are legal phenomena or, more precisely, legal institutes (institutions), ${ }^{2}$ or even more narrowly, legal rules and their effects on social welfare. But, in a broader sense, the research subject matter goes beyond the law and, for instance, includes political decision-making or effects of social norms. In this sense, there is the intersection between EAL and the public choice theory (see, for example, Rowley, 1989; Gunningham, 1992) as well as between EAL and the sociology of law (see, for instance, Cooter, 1995).

It is common for EAL to be divided into the normative EAL and the positive EAL. The difference between the two lies in the fact that the focus of the positive EAL is on the prediction which rule in the set of legal rules is more efficient, while the normative EAL prescribes the use of the efficient rule in the concrete public policy. The normative side of EAL has been the subject of criticism that boils down to the thesis that the value judgment is not the domain of economic

1 Behavioral science is a branch of science (such as psychology, sociology, or anthropology) that primarily deals with human action and often seeks to generalize about human behavior in society. Retrieved 19 August 2019, from https://www.merriam-webster.com/dictionary/ behavioral\%20science

2 While the term "institute" is commonly used in the legal jargon, the term "institution" is common in the economic literature. 
analysis. Considering this issue, we take a completely opposite view, proposed by one of the founders of EAL, Ronald Coase, who pointed out that the value estimates are not and cannot be reserved only for activists outside the economic science and that such self-restraint (proposed by some economists) is unnecessary (Coase, 1994: 47). Today, the normative basis of EAL is generally accepted, but it is commonly criticized by the BLE representatives. ${ }^{3}$

The EAL methodology is even more controversial. Namely, the main question is how to define EAL: according to the research subject, which is (as already noted) very "colorful", or according to the methodology. The consensus was offered by the famous economist Gary Becker, who stressed that economics should be defined according to the method or approach and not according to the research subject, because this economic approach can integrate a wide range of human behavior (Becker, 1976: 5).

As we already know that the method of neoclassical economics is based on the rational choice approach (the so-called homo economicus), there is no reason not to apply this reasoning to the question of EAL methodology. In other words, the rational approach can find its application in every area of social life (including the legal field) where the choice can be made. In the legal domain, the economic methodology has found its place in the field of substantive law (e.g. family law, labor law, criminal law, etc.), procedural law (e.g. choice between trial and settlement in the civil proceeding), or in auxiliary legal disciplines (such as criminology). This is a manifestation of the so-called "economic imperialism" which obviously and seriously took effect in the legal field, primarily by virtue of the efforts of the eminent lawyer Richard Posner (see, for instance, Posner, 1998).

To conclude this part, the rational choice approach is the main methodology of the neoclassical EAL, by means of which this scientific discipline had been developed. Yet, the question of EAL methodology, as well as the current trends and themes in EAL, require some additional attention.

\section{Methodology, trends and themes of Economic Analysis of Law}

There are four basic assumptions on which the rational choice approach has been established. Those are:

1. Methodological individualism, which means that individuals and theirs decisions are the subject of economic analysis;

2. Individuals make decisions in their own interest - they maximize their own expected utility;

3. Stable preferences of individuals in the short term;

4. Market equilibrium.

3 This issue will be discussed in the part related to the intersection between EAL and BLE. 
If we want to sublimate these assumptions into one sentence, we may say that "people maximize, markets clear" (Baird, 1997: 1132). This sentence reflects the core of the neoclassical economics, which was questioned primarily by the famous scientist Herbert Simon and his concept of bounded rationality, and later by other behavioral scientists, such as Daniel Kahneman, Amos Tversky, Dan Ariely, etc. The essence of the bounded rationality is embodied in the following concept: when individuals make decisions, their rationality is bound by psychological limits, especially when it comes to their computational and predictive ability (Simon, 1955: 101). As decision-makers, individuals act as satisficers, which means that they seek a satisfactory solution rather than an optimal one (for more detail see: Cristofaro, 2017). Inter alia, Simon emphasized the role of information in the decision-making process (Simon, 1955: 99). In this regard, Posner pointed out that the issue of information had already been incorporated into the neoclassical economic models without requiring an alteration in any fundamental assumptions, such as rational maximization (Posner, 1993: 80). We see that Posner consistently defends the principle of rationality by incorporating into it the question of information costs. The neoclassical economics, as well as the (neoclassical) law and economics, would not exist without rationality. So, from that point of view, this defence seems rational, particularly considering that Posner is, without any doubt, the most prominent EAL theorist. ${ }^{4}$

Besides Posner, there are other theorists who have contributed to the methodological "framing" of EAL. The most prominent among them are: Ronald Coase, the Nobel Prize laureate and one of the founding father of EAL, who became famous for his work "The Problem of Social Costs" (Coase, 1960); Guido Calabresi, who published the significant work "Some Thoughts on Risk-Distribution and the Law of Torts" (Calabresi, 1961), which paves the way for further development of EAL; and, Gary Becker, who expanded the scope of microeconomic analysis to a wider field of human behavior and interaction (marriage, family, crime). Each in their own way and sometimes from opposing standpoints, these four scholars laid the groundwork for EAL. ${ }^{5}$

Several themes and trends that enrich neoclassical law and economics research agenda (the mainstream EAL) have been highlighted in relevant literature (Mackaay, 2000: 81): the role of institutions, historical studies, strategic behavior in human interaction, limited rationality of human actors, uncertainty and entrepreneurship, the contributions of public choice and game theory, economic

4 Thus, there is a syntagm Posnerian Law and Economics.

5 Other EAL proponents are Robert Cooter and Thomas Ulen, the authors of the famous international textbook Law \& Economics (Cooter, Ulen, 2016), as well as Stiven Shavell, the author of Foundation of Economic Analysis of Law (Shavell, 2004), and many other significant EAL theorists. 
regulation, the relationship between the law and economics and sociology of law. Prima facie, some of these topics clearly indicate the relationship between EAL and another social discipline, such as psychology. Indeed, some famous psychologists (such as Kahneman and Tversky) "gave wings" to the unprecedented development of economics and EAL in the direction of emergence and development of BE and BLE. One of the key thesis of these and others authors, which has been confirmed by numerous empirical studies, is that the human reasoning does not in fact conform to the principle of rational choice in a number of ways (Elster, 1989; Kahneman, Knetsch, Thaler, 1991; Simon, 1959; Tversky, Kahneman, 1974). So, the rational behavior paradigm of the neoclassical economics has been seriously shaken by series of empirical studies.

We can conclude that the neoclassical EAL is a discipline with "flexible" methodology and heterogeneous subject of research. Special disciplines, such as BE and BLE, were "born" and developed within its framework. This raises the questions about their relationship, which will be the subject matter of further elaboration in this paper.

\section{What is Behavioral Economics?}

As already noted, incorporating insights from psychology into traditional economic analysis has spawned the field of Behavioral Economics (BE). Basically, BE provides a framework for understanding how people make real decisions. Strictly speaking, if we talk about decisions in the domain of economy (for instance, in the financial market), then the term behavioral economics is completely correct and logical. But, some of our decisions do not only have economic implications, or some decisions are not made only in the domain of economy. A classic example is our decision whether to go to trial or settlement. It implies that the subject matter of BE could not only be limited to economic decisions (as defined above) and their implications. There are many examples that support this thesis but we will constrain our attention to the Coase Theorem, because of its importance in the legal field.

The Coase Theorem (Coase, 1960) implies as follows: when a court enters a judgment, whether in the form of an injunction or a damage award, the parties are likely to bargain to a different outcome if that outcome is preferable to what the court did and if the transaction costs and wealth effects are small. In terms of the ultimate allocation of entitlements under such conditions, it is irrelevant who an entitlement is allocated to after litigation, and how it is protected (by a property rule or by a liability rule).

But, behavioral economists discovered a phenomenon, the so-called endowment effect, which entails that we put a bigger weight on things that we possess as 
related to the things that we do not possess. The endowment effect considerably changes the implications of the Coase Theorem. In other words, the assignment of a legal entitlement may well affect the outcome of bargaining, even when transaction costs and wealth effects are zero.

The endowment effect has been demonstrated by numerous experiments, the best known of which is the "coffee mugs experiment" (Kahneman, Knetsch, Thaler, 1990). In this experiment, the behavioral analysis generates a prediction distinct from the standard economic analysis. Whereas the Coase Theorem would have predicted that about half the mugs would be traded by participants, only fifteen percent of the mugs were actually traded. In this experiment, the students who were assigned coffee mugs had a strong tendency to keep them, considering that the price they asked to give up their mugs was more than twice higher than the price that the students who did not get a mug were willing to pay.

This endowment effect is a manifestation of the broader phenomenon of loss aversion, implying the idea that losses are weighed more heavily than gains, which in turn is a central building block of Kahneman and Tversky's prospect theory (Kahneman, Tversky, 1979). The prospect theory finds its application in many contexts, for example in litigation, where litigants have to decide whether to settle or to go to trial. The core of the prospect theory and its new versions - the cumulative prospect theory (Tversky and Kahneman, 1992) is a framing effect, which implies that people make different decisions (risky or less risky), depending on the (positive or negative) framework in which they decide. In a positive framework, they exhibit risk aversion, as opposed to a negative framework, in which they manifest a propensity for risk. So, if the frame in which we make decisions is relevant to our decision, it means that manipulation with a framework can alter our decisions. This is a strong message for policymakers.

Besides the endowment effect and the framing effect, there are many other systematic errors in thinking that affect our decisions, usually known as cognitive biases (Samson, 2019: 168). Cognitive biases, as a consequence of heuristic rules, boil down to the intuition bias. To date, 186 cognitive biases had been identified in the general population, and they are classified into three groups: a) decision-making, belief, and behavioral biases; b) social biases; and c) memory errors and biases. ${ }^{6}$

To sum up, BE is a subfield of economics which incorporates primarily psychological insights that radically questioned the standard economic model of rational behavior. In Thaler's words (cited in: Kaneman, 2015: 251), a real man (Human) is opposed to the imagined rational actor (Econ) whose way of thinking is not only imbued with cold and rational cost-benefit calculation. This does not mean

6 See the list of cognitive biases: https://en.wikipedia.org/wiki/List_of_cognitive_biases 
that people make systematic irrational decisions, but only that the model of rational behavior does not describe people well enough (Kaneman 2015: 386). Simply put, the bias of our intuition, as one part of our cognitive apparatus (the so-called System 1), and the slow control of its other, deliberate, rational part (the so-called System 2) make our real decisions quite different to those made by the rational actor in economic models.

On the other hand, as previously described, BE has found its application in the field of law, for instance in litigation, where many actors (such as judges, jurors, lawyers, plaintiffs, defendants, etc.) make biased decisions (see, for instance, Mojašević, Nikolić, 2018). This led to the development of another subdiscipline: Behavioral Law and Economics, whose subject matter and task will be elaborated below.

\section{What is Behavioral Law and Economics?}

In a nutshell, the task of BLE is to explore the implications of actual (not hypothesized) human behavior for the law (Jolls, Sunstein, Thaler, 1998: 1476). According to these authors (Jolls, Sunstein, Thaler, 1998: 1476-1485), there are two lines of distinctions between BLE and the conventional (neoclassical) L\&E. The first distinction considers the basic assumptions of human behavior. Namely, those assumptions are: the bounded rationality (already explained), the bounded willpower, and the bounded self-interest. The bounded willpower refers to the fact that people often make decisions or take actions that they know to be in conflict with their own long-term interests (Jolls, Sunstein, Thaler, 1998: 1479). The best examples are smokers who cannot stop smoking or savers who cannot stop spending money. The bounded self-interest is a concept which includes a notion of fairness. In other words, as opposed to the neoclassical economic models, the agent in behavioral models cares about fairness in relationships with others.

The second line of distinction between BLE and L\&E considers the predictive power of economic models, that is, how law affects people's behavior. These authors provide arguments that contradict the three fundamental principles of the neoclassical L\&E (Jolls, Sunstein, Thaler, 1998: 1481-1485). The first economic principle is that the total demand for some asset falls when its price rises. This prediction is of course correct, but this does not mean that people are optimizing. In other words, people do not always choose optimal solutions as they do in economic models. The second principle concerns the very nature of costs. Namely, actors in standard economic models usually equate opportunity costs (incurred by foregoing opportunities) with out-of-pocket costs (incurred in buying possessions) and ignore sunk costs (costs that had been actually incurred), which ultimately leads to wrong predictions. For example, if we own a 
house, we are not willing to sell it at the same price as when we wish to buy it. Estimates of the ratio of selling prices to buying prices are often at least two to one (Kahneman, Knetsch, Thaler, 1990: 1327). Another example relates to sunk costs, for instance, when one makes a decision to invest. The standard economic analysis postulates that one considers only the future consequences of one's investment, ignoring sunk costs. But, this is wrong because our decisions are also constrained by costs that we have already incurred. This is usually the reason why investors stay in a failed project or spouses remain in a bad marriage. The third fundamental principle of conventional L\&E is that "resources tend to gravitate toward their most valuable uses". But, we have already explained on the example of Coase Theorem that this principle does not work perfectly because of the existence of the endowment effect.

So, behavioral analysis does not tend to undermine the conventional L\&E principles. Rather, it seeks to detect flaws in basic assumptions, correct them and, on that basis, improves the predictive power of standard economic models. We may conclude that the proponents of BLE do not want to substitute the conventional L\&E but rather to build more realistic models of human behavior. To prove that, we will present two examples: behavioral insights in the context of legal proceedings, and behavioral insights in the context of negotiations prior to litigation.

\subsection{Behavioral insights in the context of legal proceedings}

In this section, we elaborate on the practical implications of the Coase Theorem in the context of legal proceedings. Simply put, this Theorem predicts that agents (litigants) will bargain for a better solution (settlement) as related to the one that is contained in a court judgment. For instance, if a court enters a very high damage award, parties will bargain to reach a settlement that better fits their interests, i.e. a settlement with lower damages. In that case, it would be a more efficient solution. But, we have already explained that the endowment effect suggests that the assignment of a legal entitlement may well affect the outcome of bargaining. This effect is particularly pronounced when the entitlement is prescribed and allocated to one of the (opposing) parties by a court judgment. The question is: why is it so?

We can make a parallel to a homeowner. We have seen that a homeowner (or any other holder) demonstrates a strong tendency to keep a thing which he/she already possesses. So, imagine a party who has received a court judgment in his/her favor after a litigation battle. Obviously, that party would think that he/ she deserved it, which was confirmed by experimental research (Loewenstein, Issacharoff, 1994). So, the endowment effect will be particularly strong after litigation when legal entitlement is allocated to one of the parties who believes 
that he/she deserves it or that he/she earned it. Precisely, this kind of belief can prevent agreement on settlement which would be more favorable than a court judgment. The winning party may also take pleasure in his/her victory and the other party's loss. So, in a real-world setting, we can expect fewer agreements on settlement than in neoclassical economic models, even when transactions costs and wealth effects are small.

To test this thesis, we can turn to empirical research. In the research titled "Do Parties to Nuisance Lawsuits Bargain after Judgment? (Farnsworth, 1999), the author examined about twenty nuisance cases and provided proof that in none of them did the parties even attempt to contract around the court order when transaction costs were low. Moreover, the result was similar even when an impartial third party thought there was a room for mutually acceptable agreement. To make matters worse, as reported by the interviewed lawyers, the parties would not have concluded the agreement even if the judgment had been different. This research reveals two key factors that contributed to the lack of settlement agreements: the bitterness (acrimony) between the parties, and the presence of the endowment effect.

Although there is a continuing need for empirical research that would confirm or refute the above thesis, we emphasize that neglecting the behavioral findings impairs the validity of neoclassical L\&E findings. We may also see that behavioral findings are of great importance in a similar context: during negotiations, before and after the litigation begins.

\subsection{Behavioral insights in the context of negotiations}

Based on the previous analysis, we might expect a greater number of settlements before litigation begins. But, is that correct? Are there other barriers to effective agreement between the agents (negotiators) before and after the litigation begins? What do literature and empirical studies say about that?

Recent literature (Munsinger, Philbin, 2017: 317-330) suggests that numerous cognitive biases can prevent parties from reaching an agreement during negotiation. Some of the most common biases are: optimism, anchoring, sunk costs, mental accounting, confirmation bias, the herd behavior, loss aversion, contrast effects, and compromise effects. We can add two other types of cognitive bias that can significantly undermine the negotiation process: the egocentric bias and the self-serving bias. Further on, we explain the biases that have not been already addressed and examine their influence on the negotiation process.

The egocentric bias implies a tendency to overestimate one's own abilities. It arises in many spheres of life, including professional skills, health, driving skills, 
contribution to joint activities, marriage, etc. (see, for instance, Weinstein, 1980; Svenson, 1981; Cross, 1997; Ross, Sicoly, 1979; Baker, Emery, 1993). Despite some similarity and frequent confusion, a distinction should be made between the egocentric bias and a tendency to attribute merits to oneself in case of success, and blaming other people or circumstances for failure (the self-serving bias). The latter bias can be characterized as favoring oneself and self-interest (Forsyth, 2007, 429). As empirical evidence suggests (Babcock, Loewenstein, 1997), the parties and their attorneys are prone to this kind of bias in terms of their own abilities, the quality of representation, and the relative value of their case, which can significantly undermine the settlement process. Interestingly, as this study shows (Babcock, Loewenstein, 1997: 120), as soon as a certain asymmetry between negotiators is included in the experiment (e.g. a subtle difference in roles), there is a change in the perception of a fair agreement in the direction of the personal interest of each negotiator; negotiators also believe that their own concept of fairness is impartial. On the other hand, before the introduction of asymmetry, the negotiators considered that it was fair to split the cake in half. Therefore, some shift towards self-interest is obvious. Another experimental study (Loewenstein, Issacharoff, Camerer, Babcock, 1993) shows that the parties' egocentric propensity leads to a lower likelihood of settlement and unnecessary litigation. In this experiment, depending on the role (the plaintiff or the defendant), the parties differently assessed what they considered to be the fair amount of settlement. Namely, the plaintiffs always sought a higher amount of settlement than the defendants, confirming that their different interpretation of the case facts was biased, i.e. in their own interest.

The optimistic bias is a general tendency to see things in a positive frame. Although this tendency is useful in many aspects of life, it may have negative consequences in the domain of legal disputes, where realistic assessment of cases is of great importance. Although the disputing parties may be expected to be the only ones that are prone to this bias, lawyers have not been spared either. As noted (McElhaney, 2012), there is a lawyer's tendency "to fall in love with a case", which can significantly diminish his/her client's chances of winning a dispute or concluding a settlement. If a lawyer "falls in love with a case", he/ she cannot objectively and realistically see it. He/she will underestimate the strengths of the other side's arguments and overestimate the strengths of his/ her position. So, as some authors report (David, 2016), bad mood and negative feelings have benefits too, because one is able (especially as a lawyer) to generate better arguments, recall facts more clearly, examine facts in a fresh and creative way, and reason more effectively. In a word, the bad mood activates the already-mentioned System 2 of our cognitive apparatus. 
The anchoring effect implies a human tendency to unconsciously rely on a piece of information (the so-called "anchor") when making decisions, even if it is insignificant. Numerous experiments confirm the existence of the anchor (see, for example, Tversky, Kahneman, 1974: 1128). Negotiators are more or less inclined to accept a final settlement offer, depending on what the other party's initial offer was. Obviously, that initial offer shapes the negotiators' expectations and their preferences in negotiations (Korobkin, Guthrie, 1994). This research showed that plaintiffs were less likely to accept a final settlement offer if it was preceded by a reasonable initial offer than when it was preceded by an extreme initial offer or no initial offer. Besides the anchoring effect, another tendency emerged in this case: avoiding cognitive dissonance. Namely, negotiators are more likely to reject a final settlement offer if they have previously rejected it, as compared to those negotiators who have not received a previous offer at all, as they avoid the inconvenience (tension) they have previously experienced. But, it is wrong to think that taking an extreme position early in a negotiation always pays off. Quite opposite to the conventional wisdom, an early extreme position more often produces an impasse or requires a larger concession later in negotiation. The same can be said for a too low first offer in negotiation process. So, it is usually more prudent to start with an offer that is perceived as reasonable under local convention (Munsinger, Philbin, 2017: 321-323).

The mental accounting refers to the tendency that people treat money differently, depending on factors such as the source of funds or the purpose of the account. Actually, people separate assets into different (mental) accounts rather than treating all assets as money equivalents (see, for instance, Thaler, 1999). This cognitive bias might also influence the negotiation outcome. For instance, if one of the negotiators is emotionally attached to the house which is objectively only one source of funds, it can be a strong barrier in negotiating an agreement.

The confirmation bias refers to the tendency to seek out or evaluate information in a way that fits one's existing thinking and preconceptions (Samson, 2019: 169). If people make inferences from confirming evidence and ignore facts that contradict their beliefs, it can obviously lead to wrong conclusions. It is quite clear that this bias is particularly pronounced in the legal field, i.e. between the parties and their lawyers in negotiation. In particular, if lawyers "fall in love with a case", they are biased in pursuing arguments that are in their favour and the clients' best interest, and those that are at the detriment of the other party. It follows that the confirmation bias might be a strong barrier to agreement.

The herd behavior means that people do what others are doing instead of using their own information or making independent decisions (Samson, 2019: 176). Simply put, it is a tendency to copy behavior of others in a group. It is a well-known concept 
in social psychology that is also applied in behavioral finance in relation to the irrationality of investors, including stock market bubbles. Speculative stock market bubbles are fueled by contagious investor enthusiasm (herd behavior) and stories that justify price increases (see, for instance, Shiller, 2015). In litigation, it can have a distorting effects if, for example, the parties who copy the behavior of other parties decide to go to trial instead of resorting to bargaining and trying to reach an agreement.

The contrast effect implies that people are likely to evaluate an existing option more favorably when a similar but inferior option is added to the set of choices. It is reasonable to assume that this contrast effect is present in negotiation when a negotiator considers a set of options and when another option is subsequently introduced. That additional option, even without having any relevant information value in terms of the options under consideration, might alter the negotiators' assessment. This finding has been confirmed by a series of studies (see, for example, Guthrie, 2003: 617-621). In this experiment (where first-year law students were asked to negotiate the sale of a painting), the presence of a third option (giving the painting to the law partner in exchange for payment in four installments of $\$ 5,000$ ) dramatically increased the attractiveness of the first option (giving the painting to the law partner in exchange for an immediate payment of $\$ 20,000$ ) over the second option (selling the painting and then splitting the $\$ 40,000$ proceeds equally). The third option is similar to but obviously inferior to the first one, which increased its attractiveness and altered the participants' choice. Apparently, the contrast effect is at work.

The compromise effect is another form of context dependence, similar to the contrast effect, which can induce suboptimal decision making in multiple-option negotiation. The compromise effect suggests that people prefer to choose "medium" rather than extreme options in the set of choices. In an experiment similar to the aforementioned one (Guthrie, 2003: 622-625), the presence of this effect in the negotiation was demonstrated. Namely, participants had to choose between two plots of land: one was more attractive in price (the first choice) and the other was more attractive in location (the second choice). In this case, they could not compromise between the two options. But, the introduction of the third option (the plot that is the most expensive but also the most attractive in location) made the second choice most attractive. It was a compromise in that case.

As we have seen, there are a number of factors that affect the outcome of negotiations that have been neglected by standard economic models. Behavioral models correct these errors and provide more accurate findings. 


\section{Conclusion}

The conclusions of this paper may be summarized in several points. First, the rational choice approach (based on homo economicus) is the main EAL methodology, by means of which this scientific discipline has been developed. Meantime, as behavioral science developed, the neoclassical EAL willingly or reluctantly "borrowed" some methods from other social disciplines (primarily from psychology) so that its methodology has become quite heterogeneous. These behavioral findings also led to the development of a new subject-specific discipline: Behavioral Law and Economics, which further raises a question of their relationship and future development.

Behavioral Law and Economics (BLE) indicates that many predictions of standard economic models are wrong because they are based on false assumptions about human behavior. As compared to the standard economic theory predictions, people can be more spiteful and more cooperative in reality. We have shown on the example of the Coase Theorem that people are not always inclined to agree on settlement, at least not as predicted by the Theorem. Even in a world without transaction costs and no wealth effect, the assignment of (property) rights alters the ultimate allocation of those rights. In the example of court rulings, we have seen that prescribing and giving an entitlement to one of the disputing parties has a significant impact on the outcome of potential negotiations between the parties at the end of the trial. As revealed by behaviorists, the endowment effect provides an explanation of such an impact.

We have also seen that many others behavioral concepts explain the litigants' or negotiators' behavior quite well. So, many "loopholes" that have existed in the standard assumptions of economic models are being filled in with more realistic $\mathrm{BE}$ and BLE concepts. The examples of the contrast effect and the compromise effect clearly describe the choices that negotiators made in different contexts. Also, economic theory assumes that choices are invariant to the manner in which a problem is framed. As already noted, the prospect theory and the framing effect have completely rejected this conception. Then, as BLE demonstrates, ignoring the concept of fairness (especially the perception of fairness contained in the aforementioned idea of bounded self-interest) in standard economic theory is completely wrong. This concept is highly important regarding the content of law, i.e. what is right and what is wrong. So, those and many other effects and cognitive biases have been neglected in standard economics models, thus leading to wrong predictions and bad conclusions. This has had a profound effect on the public policy-making in various domains, with many detrimental consequences.

In connection with this last issue, the question of the quality of normative policy proposed by EAL, as compared to the normative policy of BE and BLE, has been 
raised. This question requires further elaboration and will be the subject of future research. But, Behavioral Law and Economics, with its behavioral findings, may be said to have significantly shaken up the previous views of normative politics in different domains.

To conclude, considering the development of Behavioral Law and Economics thus far, the credibility of its findings and its normative implications, we think that there is no reason to doubt that this discipline will develop in the future as a fully independent discipline and that Law and Economics may eventually turn into Behavioral Law and Economics. Until then, incorporating the BLE findings into standard economic models seems inevitable.

\section{References}

Babcock, L., Loewenstein, G. (1997). Explaining Bargaining Impasse: The Role of Self-Serving Biases. Journal of Economic Perspectives. 11(1). 109-126

Baird, D. (1997). The Future of Law and Economics: Looking Forward. University of Chicago Law Review. 64.1129-1165

Baker, L., Emery, R. (1993). When Every Relationship Is Above Average: Perceptions and Expectations of Divorce at the Time of Marriage. Law and Human Behavior. 17(4). 439-450

Becker, G. (1976). The Economic Approach to Human Behavior. Chicago: University of Chicago Press

Calabresi, G. (1961). Some Thoughts on Risk-Distribution and the Law of Torts. The Yale Law Journal. 70(4). 499-553

Coase, R. (1960). The Problem of Social Cost. Journal of Law and Economics. 3. 1-44

Coase, R. (1994). Essays on Economics and Economists. Chicago: University of Chicago Press

Cooter, R. (1995). Law and Unified Social Theory. Journal of Law and Society. 22. 50-67

Cooter, R., Ulen, T. (2016). Law \& Economics (sixth edition). Boston, Columbus, Indianapolis, New York, San Francisco, Upper Saddle River, Amsterdam, Cape Town, Dubai, London, Madrid, Milan, Munich, Paris, Montréal, Toronto, Delhi, Mexico, City Sao Paulo, Sydney, Hong Kong, Seoul, Singapore, Taipei, Tokyo: Addison-Wesley

Cross, P. (1997). Not Can, But Will College Teaching Be Improved?. New Direction for Higher Education. 17. 1-15 
David, S. (2016). Don't Worry, Be Gloomy: Negative Feelings Have Benefits Too. Retrieved 20 August 2019, from http://www.health.com/mind-body/negativity-benefits

Elster, J. (1989). Nuts and Bolts for the Social Sciences. Cambridge: Cambridge University Press

Farnsworth, W. (1999). Do Parties to Nuisance Lawsuits Bargain After Judgment? A Glimpse Inside the Cathedral. The University of Chicago Law Review. 66(2), 373-436

Forsyth, D. (2007). Self-Serving Bias. In William A. Darity (Ed.), International Encyclopedia of the Social Sciences (p. 429). Detroit: Macmillan Reference

Gunningham, N. (1992). Public Choice: The Economic Analysis of Public Law. Federal Law Review. 21. 117-135

Guthrie, C. (2003). Panacea or Pandora's Box?: The Costs of Options in Negotiation. Iowa Law Review. 88. 601-653

Jolls, C., Sunstein, C., Thaler, R. (1998). A Behavioral Approach to Law and Economics. Stanford Law Review. 50. 1471-1550

Kahneman, D., Knetsch, J., Thaler, R. (1990). Experimental Tests of the Endowment Effect and the Coase Theorem. Journal of Political Economy. 98(6). $1325-1348$

Kahneman, D., Knetsch, J., Thaler, R. (1991). The Endowment Effect, Loss Aversion, and Status Quo Bias. Journal of Economic Perspectives. 5. 193-206

Kahneman, D., Tversky, A. (1979). Prospect Theory: An Analysis of Decision under Risk. Econometrica. 47(2), 263-292

Kaneman, D. (2015). Misliti brzo i sporo (Thinking Fast and Slow). Smederevo: Heliks

Korobkin, R., Guthrie, C. (1994). Opening Offers and Out-of-Court Settlement: A Little Moderation May Not Go a Long Way. The Ohio State Journal on Dispute Resolution. 10(1). 1-22

Loewenstein, G., Issacharoff, S. (1994). Source Dependence in the Valuation of Objects. Journal of Behavioral Decision Making. 7(3). 157-168

Loewenstein, G., Issacharoff, S., Camerer, C., Babcock, L. (1993). Self-Serving Assessments of Fairness and Pretrial Bargaining. Journal of Legal Studies. 22. 135-159 
Mackaay, E. (2000). History of Law and Economics. In B. Bouckaert, G. De Geest, (Ed.), Encyclopedia of Law and Economics. Volume I. The History and Methodology of Law and Economics (pp. 65-117). Cheltenham: Edward Elgar

McElhaney, J. (2012). Don't Be Seduced: Falling in Love with Your Case Means You Won't See Its Shortcomings. ABA Journal. Retrieved 15 August 2019, from http:// www.abajournal.com/magazine/article/dont_be_seduced_falling_in_love_with_ your_case_means_you_wont_see_its_short

Mojašević, A., Nikolić, Lj. (2018). Когнитивне пристрасности у правној области: место сусрета правне и бихевиористичке науке (Cognitive Biases in the Legal Field: a Meeting Place of Legal and Behavioral Science). Zbornik radova Pravnog fakulteta u Nišu (Collection of Papers of the Faculty of Law in Niš). 79. 253-273

Munsinger, H., Philbin, D. (2017). Why Can't They Settle? The Psychology of Relational Disputes. Cardozo Journal of Conflict Resolution. 18. 311-362

Posner, R. (1993). The New Institutional Economics Meets Law and Economics. Journal of Institutional and Theoretical Economics. 149. 73-87

Posner, R. (1998). Economic Analysis of Law. New York: Aspen Law \& Business

Ross, M., Sicoly, F. (1979). Egocentric Biases in Availability and Attribution. Journal of Personality and Social Psychology. 37(3). 322-336

Rowley, C. (1989). Public Choice and the Economic Analysis of Law. Boston: Cluwer Academic Publishers

Samson, A. (Ed.)(2019). The Behavioral Economics Guide 2019 (with an Introduction by Uri Gneezy). Retrieved 29 July 2019, from https://www.behavioraleconomics.com

Shavell, S. (2004). Foundations of Economic Analysis of Law. Cambridge: Belknap Press of Harvard University Press

Shiller, R. (2015). Irrational exuberance. Princeton: Princeton University Press

Simon, H. (1955). A Behavioral Model of Rational Choice. The Quarterly Journal of Economics. 69(1). 99-118

Simon, H. (1959). Theories of Decision-Making in Economics and Behavioral Science. American Economic Review. 49. 253-283

Svenson, O. (1981). Are We All Less Risky and More Skillful Than Our Fellow Drivers?. Acta Psychologica. 47(2). 143-148 
Thaler, R. (1999). Mental accounting matters. Journal of Behavioral Decision Making. 12. 183-206.

Tversky, A. Kahneman, D. (1974). Judgment under Uncertainty: Heuristics and Biases, Science. 185. 1124-1131

Weinstein, N. (1980). Unrealistic Optimism about Future Life Events. Journal of Personality and Social Psychology. 39(5). 806-820

\title{
Др Александар С. Мојашевић,
}

Ванредни професор,

Правни факултет, Универзитет у Нишу

\section{БИХЕВИОРИСТИЧКО ПРАВО И ЕКОНОМИЈА: МУЛТИДИСЦИПЛИНАРНОСТ НА ДЕЛУ}

\begin{abstract}
Резиме
У овом раду се представљају теоријске основе бихевиористичког права и економије (БПЕ), као и практичне импликације кључних налаза ове дисциплине. Како је текао развој БПЕ, где леже корени ове дисциплине, ко су њени најзначајнији представници, али и опонентни, и, најважније, где су границе ове научне дисциплине у односу на неокласичну економску анализу права, с једне стране, и бихевиористичку економију, с друге стране? Будући да БПЕ „позајмљује” одређене психолошке налазе (нарочито налазе социјалне психологије), поставља се и питање повезаности ових двеју дисциплина, те ће и оно бити узгред анализирано. Све у свему, централно питање, на које је потребно одговорити, гласи: да ли је БПЕ данас посебна и довољно изграђена научна дисциплина, или је она само теоријска надоградња над својом базом (неокласичном економском анализом права) и који су практични домети и значај њених кључних налаза на пољу политике решавања спорова?
\end{abstract}

Кључне речи: Бихевиористичко право и економија, Економска анализа права, Бихевиористичка економија, теоријске основе, практични налази.

7 Овај чланак је резултат рада у оквиру пројекта под називом „Заштита људских и мањинских права у европском правном простору“, финансираног од стране Министарства просвете и науке Републике Србије (референтни број 179046). 